\title{
Process Management and Robotic Process Automation: The Insights from Systematic Literature Review
}

\begin{abstract}
During the Fourth Industrial Revolution, the digital transformation revolutionised both individual organisations and entire industries. One such advanced technology is Robotic Process Automation (RPA). However, organisations do not always make the progress by using the RPA to increase the efficiency of their business processes. The scientific sources lack the synthesis of Process Management (PM) and RPA and insights into their interrelationship. This article aims to fill the gap in the systematic analysis of interrelations between PM and RPA from a managerial perspective by identifying less researched areas and formulating insights and recommendations for future research.
\end{abstract}

Keywords: process management, robotic process automation, business process management.

Ketvirtosios pramonès revoliucijos laikotarpiu skaitmeninè transformacija revoliucionizuoja tiek individualias organizacijas, tiek ištisas industrijas. Viena iš tokių pažangių technologijų - robotinis procesų automatizavimas. Vis dèlto ne visuomet organizacijos pasiekia pažangą, pasitelkdamos veiklos procesų efektyvumui didinti RPA. Mokslinejje literatūroje stokojama procesų vadybos ir RPA tematikų sintezès, įžvalgų jų tarpusavio sąsajų tema. Šiame straipsnyje, taikant sisteminès literatūros apžvalgos metodą, siekiama užpildyti spragą procesų vadybos ir RPA sąsajų tematika vadybiniu aspektu, taip identifikuojant mažiau tyrinètas sritis ir suformuluojant rekomendacijas būsimiems tyrimams.

Raktiniai žodžiai: procesų vadyba, robotinis procesų automatizavimas, verslo procesų vadyba.

\section{Introduction}

The Fourth Industrial Revolution is a concept that is fundamentally changing society and the economy. The outcomes of this revolution are so significant that its impact can hardly be overestimated (Bloem et al., 2014; Kumar and Balaramachandran, 2018). In recent years, the changes taking place, referred to by researchers as the digital transformation, are revolutionising both individual organisations and entire industries, changing the economic environment of organisations. Organisations consistently focus on innovative strategies, look for new ways to develop business processes, thus creating their uniqueness (Anagnoste, 2018a; Fischer et al., 2019; Thomas, 2020; Siderska, 2020). For this, they focus on flexible workflows,

\footnotetext{
Inga STRAVINSKIENE - PhD student at the Faculty of Economics and Business Administration, Vilnius University, Lithuania. Address: Sauletekio Ave. 9, LT-10222, Vilnius, Lithuania. Phone: +370 67753304. Email: inga.stravinskiene@evaf.vu.lt
}

Dalius SERAFINAS - professor at the Faculty of Economics and Business Administration, Vilnius University, Lithuania. Address: Sauletekio Ave. 9, LT-10222, Vilnius, Lithuania. Phone: +370 68776262. Email: dalius.serafinas@evaf.vu.lt. 
automated decision management, and evolving software architecture (Onar and Ustundag, 2018; Fischer et al., 2019; Ranerup and Henriksen, 2019). However, despite the rapid wave of the application of new technologies, the planned success is not always guaranteed (Brocke et al., 2018). The management processes for the successful application and administration of these technologies are still unclear. Managerial decisions in the context of digitisation are not substantiated in the scientific literature (Jirsak et al., 2016, Moeuf et al., 2018; cit. in Martinez, 2019).

According to J. Siderska (2020), the rapidly changing market requirements and the dynamic development of IT contribute significantly to the evolution of modern management concepts that use IT. One of the principles of the Fourth Industrial Revolution is integrated business processes (Akdil et al., 2018). Therefore, business and digital technology management gradually become interrelated and gain special significance (Thomas, 2020). It is emphasised that processes are the arterial system in organisations and inter-organisational supply chains (Dumas et al., 2018). For this reason, Business Process Management is in the spotlight in modern organisations (Pereira et al., 2019), and the interest of organisations in the concept of process-oriented organisation is growing (Szelagowski and BerniakWoźny, 2020).

In today's era, the evolution of robots is rising, with workplaces being rapidly robotised. Technology no longer plays a merely ancillary role but replaces manual labour (Anagnoste, 2017; Siderska, 2020). Three commonly identified technologies are suitable to change and improve supply chain business processes: Robotic Process
Automation, Artificial Intelligence, and Blockchain (Hartley and Sawaya, 2019). This article analyses one specific digital technology, Robotic Process Automation (RPA), the administration of which forces us to rethink the essential principles of management (Mamoghli et al., 2018). In recent years, interest in RPA in today's industry has grown significantly (Syed et al., 2020). However, according to newer statistics, even 30-50 per cent of RPA initiatives fail (Kirchmer and Franz, 2019).

The interrelationship between RPA and Business Process Management is a modern, new topic that received increasing attention from academic researchers in recent years. RPA is becoming an essential tool in the field of Business Process Management (Šimek and Šperka, 2019b). According to D. Fernandez and A. Aman (2018), RPA technology has a significant impact on the individual and the organisation as a whole. However, the implementation of the RPA is a challenge. As with all innovations, to achieve maximum results, organisations must learn to manage the introduction of RPA (Lacity et al., 2015; Leshob et al., 2018). Although RPA is a relatively new leading process technology, it is a trendy, high-profile topic in both the professional world and the press. However, there is a lack of synthesis and empirical research on the issues of RPA in the scientific literature. RPA topic in the academic environment is in its infancy. It is a research issue in modern organisations and industries (Ivančić et al., 2019; Hofmann et al., 2020; Šimek and Šperka, 2019b; Kokina and Blanchette, 2019; Santos et al., 2020). Thus, this article aims to fill the gap in the systematic analysis of interrelations between PM and RPA by identifying less researched areas and 


\section{Identification of keywords:}

"Robotic process automation" OR "RPA" AND

"process management" in the titles, keywords, and abstracts.

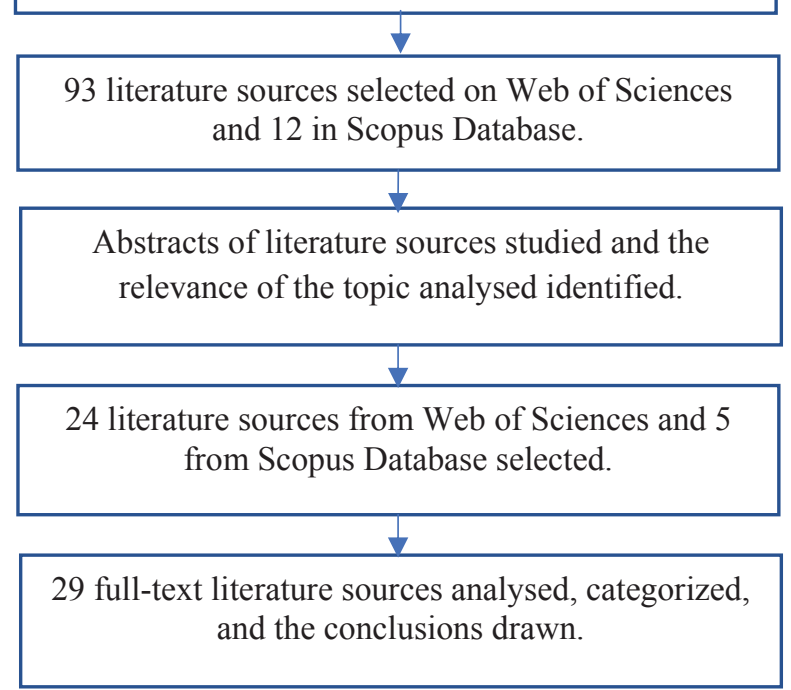

Fig. 1. Systematic literature review

Source: the authors' personal study.

formulating insights and recommendations for future research. The scientific question is what the interrelationship between PM and RPA from the managerial perspective is.

The research object is the interrelationship between PM and RPA from the managerial perspective. The article aims to reveal evolving research trends by presenting the results of a systematic literature review on PM and Robotic Process Automation from a managerial perspective.

The research methods. For this purpose, we used the method of systematic literature review. Quantitatively, the study has been based on the classification of the relevant literature. The scientific papers have been analysed in qualitative terms.
The objectives of the article are: 1) to identify the articles that describe PM and Robotic Process Automation from a managerial point of view in Clarivate Analytics/ Web of Science (WoS) and Scopus databases; 2) to classify and code these articles depending on different characteristics; 3) to provide recommendations for future investigations, identifying the most significant gaps in the research of this area.

\section{Methodology}

Literature reviews establish the foundation of academic inquires and are an essential feature of academic research. Fundamentally, knowledge advancement must be built on prior existing work (Xiao 
and Watson, 2019). Thus, to systematise the current scientific knowledge and evaluate the gaps in the research on PM and RPA, a systematic review of the literature was conducted in both quantitative and qualitative terms. Quantitatively, the article is based on a classification approach. The analysis was based on the stages of the systematic literature review conducted by Ch. J. Ch. Jabbour (2013), provided in Figure 1.

The first stage of the study was conducted in January 2021. The articles related to PM and Robotic Process Automation were systematically searched for on the largest databases - Clarivate Analytics/Web of Science (WoS) and Scopus. According to Q. Wang and L. Waltman (2016), WoS, produced by Thomson Reuters, and Scopus, produced by Elsevier, are the two most important multidisciplinary bibliographic databases that include various sources, such as journals, conference proceedings, and books. They both provide a classification system at the level of journals (Wang and Waltman, 2016).

The search in the databases mentioned above was performed according to pre-identified keywords (Table 1), which reflect the possible interrelationship between the maturity of Process Management and Robotic Process Automation. The search included the titles, abstracts, and the keywords of the articles singled out by the authors. It used the keywords such as Process Management, Robotic Process Automation, and the abbreviation RPA for the latter term.

The specific criteria such as language (selected English); document type (selected Articles, Proceedings Papers, Review Articles); timespan (selected 1990-2021), and defined categories (selected Management, Operations Research Management Sciences, Business, Business Finances, Economics) were used for the search to ensure the relevance of the selected articles. The Web of Science database search for these sources provided 93 documents. In the Scopus database, the period of 1990-2021 was chosen as well. The selected subject areas included Business, Management and Accounting; the document type indicated was an article, conference review, conference paper. Finally, 12 documents of the mentioned types were found in the Scopus database. Thus, a total of 105 scientific documents were identified through this search.

In the second stage of the research, abstracts of the selected scientific documents were carefully read to determine the relevance of these investigations to the topic, i.e., the interrelationship between PM and RPA. Only the scientific papers that corresponded to the topic analysed

Table 1 The combinations of keywords used in the search

\begin{tabular}{|c|c|}
\hline Database & Keywords \\
\hline $\begin{array}{l}\text { Clarivate Analytics/Web of Science } \\
\text { (WoS) }\end{array}$ & $\begin{array}{c}\text { TS = Topic (include Title, Abstract, Author Keywords, Keywords } \\
\left.\text { Plus }{ }^{\circledast}\right) \\
\text { TS = (Robotic Process Automation OR RPA AND Process } \\
\text { Management })\end{array}$ \\
\hline Scopus & $\begin{array}{l}\text { TITLE-ABS-KEY ("Robotic Process Automation" OR "RPA" AND } \\
\text { "Process Management") }\end{array}$ \\
\hline
\end{tabular}

Source: the authors' personal study. 
were selected. The articles that did not research PM and RPA, or could not be downloaded, were not included in the study. Some papers did not analyse the interrelationship or analysed only one aspect without relating it to the organisation $\mathrm{PM}$, the value it creates, its potential benefits, the improvement of the performance and reinforcement of the competitiveness of the organisation, or they were about automation in general without accentuating RPA. These articles were excluded from systematic analysis. Thus, out of 93 documents selected in the WoS database, 24 suitable were chosen (which comprises 25.8 per cent of all selected WoS documents). 18 scientific papers could not be accessed, and 51 were identified as inexpedient in terms of content. Meanwhile, out of 12 sources in the Scopus database, 5 scientific papers corresponded to the topic analysed (which accounts for 41.7 per cent of all selected Scopus articles). Three papers duplicated with articles found in the WoS database, and the other 4 did not match the content.

In the third stage, the research subjects were classified using the framework proposed by L. B. L. Amui et al. (2017). This model was selected following the adapted L. B. L. Amui et al. (2017) classification model used in the study of M. Buzavaite and R. Korsakiene (2019). It considers the national research context (coded as emerging, developing, developed countries), economic sector (coded as manufacturing; services; manufacturing and services), geographical region (coded as America, Asia, Europe, Africa, Oceania, several continents), the practices (coded as technical, human), research methods (quantitative studies/survey, qualitative studies/case studies/interviews, conceptual studies and (or) reviews). The last stage of the classification model focuses on analysing the results obtained and identifying the main gaps. Finally, this article performs a qualitative analysis of scientific sources, which leads to the study of the research conducted and possible directions for future research.

\section{Literature review}

This section of the literature review presents the interrelationship PM and RPA from a managerial perspective. First, the concepts of PM and RPA and their interrelationship from the managerial point of view are presented. Then, the analysis of the selected scientific items was conducted following L. B. L. Amui et al. (2017) classification model, which covers the national context, economic sector, geographical region, technical and human aspects, and research methods, is provided.

\section{The Interrelationship between Process Management and Robotic Process Automation}

Over the past ten years, emerging technologies have disrupted business processes, business models, and markets (Yunus et al., 2019). As S. Anagnoste (2017) states, "once in a while, there comes a technology that disrupts how things are "usually done" in a business" (p. 676). It is argued that the entire workplace will be radically changed in the future by people working with robots. Especially when the $\mathrm{Z}$ and Alpha Generations, who are unaware of life without the Internet, enter the 
labour market. A completely different strategy will be needed to attract, retain, and engage them (Anagnoste, 2018b). In the same context, almost every job will be restructured. Therefore, organisations will need to consider how they work, organise their work, and plan future growth. Newly configured jobs will emerge from such work redesign (Fernandez and Aman, 2018; Willcocks, 2020).

The dynamic environment and more and more educated users pose many challenges to managing organisational processes. Meanwhile, each technology provides an opportunity for an organisation to innovate (Šimek and Šperka, 2019b). The technologies are designed to give a possibility to optimise management processes and develop organisations, bringing a new level of efficiency and quality of customer service (Raissa et al., 2019). Obviously, this is inevitably linked to PM, as the RPA solution pursues the same aims, i.e., process improvement and opportunities to enhance the performance of the organisation (Fernandez and Aman, 2018; Šimek and Šperka, 2019b). Process improvement focuses on Business Process Management, which has evolved and is also influenced by technology from a more radical form like Business Process Reengineering to a more agile and continuous state (Šimek and Šperka, 2019b). Business Process Management is treated as a multidimensional approach that aims to achieve better business performance through constant process improvement, optimisation, and digital transformation (Ivančić et al., 2019). IT, meanwhile, is seen as a critical process improvement enabler that manages interactions between processes and users and focuses on business process automation. Technologies precondition the transformation of business processes for them to become efficient, agile, meet compliance requirements, develop users' experiences, or improve the overall quality of the outcomes in general (Das, 2019; Kirchmer and Franz, 2019). One of the significant digital transformation trends is business process automation (Sobczak, 2019), which is performed by one of the IT technologies - Robotic Process Automation (RPA).

The term "Robotic Process Automation" dates back to around the early 2000s (Fernandez and Aman, 2018). However, it was used for the first time in a paper prepared by the analytical company HfS Research in 2012 (Fersht and Slaby, cit. in Sobczak 2019). RPA is often closely associated with service robots, large machines, not software (Figueiredo and Pinto, 2020). However, nowadays, RPA is a software robot that can be used to automate repetitive, routine, rule-based human work, leading to cost reduction, increased desired outcomes, and faster processing. This means that RPA, as a software robot, is designed to execute business processes that depend on computer applications (Anagnoste, 2017, 2018a; Davenport, 2018; cit. in Figueiredo and Pinto, 2020; Šimek and Šperka, 2019b; Ivančić et al., 2019; Kokina and Blanchette, 2019) and can generate significant returns on investment for companies (Hallikainen et al., 2018), which creates benefits for the organisation (Ivančić et al., 2019).

RPA is seen as the first step to digital transformation in an organisation. For instance, a study conducted in 2018 found that over 60 per cent of the supply chain professionals surveyed explored or used RPA to automate supply chain business processes (APQC 2018, cit. Hartley and 
Sawaya, 2019). Cooperation among RPA and human operators will enhance and restructure existing processes (Fernandez and Aman, 2018). Even though automation offers new opportunities for redesigning business processes, not everything can be digital. The subsequent development of operations to increase process efficiency can make it possible to combine RPA with Artificial Intelligence, Machine Learning, and the like (Anagnoste, 2018b; Korhonen et al., 2020; Santos et al., 2020). It is emphasised that process improvement and optimisation are essential aspects before automation (Hofmann et al., 2020).

It is important to note that this new era of such disruptive technologies as the Internet of Things, Robotic Process Automation, Virtual Reality not only contributes to the growth of the market but also changes the individual experience in using new technologies. Employees are usually not interested in how profitable the organisation they work for is. It is more vital for them to understand how new technology will transform their lives for the better (Yunus et al., 2019). The Fourth Industrial Revolution is expected to liberate man from monotonous work and provide opportunities to expand more intelligent and creative work (Raissa et al., 2019). Therefore, in this context, it is not only the level of an organisation but also the status of an individual in the organisation that is made relevant.

The RPA, which has been evolving during the current Robotic Revolution that follows the Industrial Revolution and the Manufacturing Revolution, is the next step after the Internet, Enterprise Resource Planning (ERP), Customer Relationship System (CRM), Cloud Computing, etc. (Anagnoste, 2017). RPA is gradually entering a state of maturity (Anagnoste, 2018b; Šimek and Šperka, 2019b). The application of this technology has increased dramatically in recent years (Cooper et al., 2019). The number of scientific publications on using this technology is growing (Šimek and Šperka, 2019a).

The importance of RPA is momentous in the sectors such as Shared Services Centres and Business Process Outsourced (BPO) (Anagnoste, 2017). The most appropriate application of the RPA solution is to automate processes in the areas such as finance, accounting, procurement, human resources, supply chain, administrative activities, in particular due to the scope, regularity and consistent execution of these processes (Zaharia-Răduescu et al., 2017; Anagnoste, 2018b; Figueiredo and Pinto, 2020). However, U. Raissa et al. (2019) emphasise that the robotisation of processes can be applied to all sorts of organisational functions and can achieve good results in various industries wherever there are manual and often repetitive tasks. The application of RPA will also expand to the public sector in the coming years. RPA is suitable for large, medium, and small organisations (Anagnoste, $2018 b)$. The need for automation is associated with such problems as high data entry volumes, high error rates, significant rework, numerous manual processes, and high turnover due to repetitive/low value-added activities (Anagnoste, 2017).

The value generated by RPA is multidimensional and evolving (Kokina and Blanchette, 2019). This business-oriented technology is intended to improve the efficiency of processes and the effectiveness of services (Huang et al., 2019). The highlighted advantages of RPA are the 
swift adoption of this technology by users without any help from external consultants. It should also be noted that the RPA solution does not require technical education for process design. In this way, people from different departments can be mobilised in a so-called Excellence Centre. The Lean methodology can monitor these robots to avoid further disruption of the organisation (Anagnoste, 2017). When performing tasks, the robot can identify exceptions for manual work, eliminate unnecessary time, record the actions taken, which reduces the likelihood of human error and improves data accuracy. This robot can work 24/7, during holidays and weekends. Tasks can be completed quickly; the operations proceed with the existing architecture; data entry costs are reduced by up to 70 per cent (Anagnoste, 2017; Radke et al., 2020). It is generally accepted that one robot equals three fulltime human equivalents, as it can operate 24 hours without a break (Tripathi, 2018, cit. in Figueiredo and Pinto, 2020). Having automated processes, the benefits of RPA for an organisation are seen exceptionally quickly, in 3 to 5 weeks (Anagnoste, 2018b). In other words, RPA is an opportunity to significantly increase process efficiency, improve quality, and eliminate unnecessary processes (Cooper et al., 2019; Šimek and Šperka, 2019b; Kokina and Blanchette, 2019). At the same time, despite the initial fear of losing the job, employees' job satisfaction increases. However, the organisations that replace humans with robots challenge competition between them (Cooper et al., 2019; Fernandez and Aman, 2018). Organisations need to help employees prepare for these technology-driven changes by teaching them how to use RPA, explaining the benefits and limitations of this technology (Fernandez and Aman, 2018). In this way, the link with Business Process Management as a holistic management approach is reinforced (Šimek and Šperka, 2019b). RPA has the potential to revolutionise the ways business processes have been managed and understood by individuals till now (IRPA 2014, cit. in Fernandez and Aman, 2018). However, the analytical aspect of an organisation cannot be entirely replaced by robots yet (Fernandez and Aman, 2018). Thus, when introducing RPA, organisations can pursue goals such as process performance, efficiency, scalability, auditability, security, convenience, and compliance (Hofmann et al., 2020). They will provide better ways to operate the business, serve customers, and compete (Yunus et al., 2019).

The interrelationship between PM and RPA can be summarised by the insight of F. Santos et al. (2020), who note that the responsibility for the administration of RPA and the benefits it creates lies with the organisation, i.e., on the business side. However, there is sometimes an unclear division between the business side and the IT side. The reason for this is that RPA is an IT tool that automates the processes belonging to the business side. In other words, perceived narrowly, RPA is treated as a rapidly evolving software robot. However, in a broad sense, it is a particular type of organisational and technological change that leads to developing a hybrid work environment in which humans and robots cooperate. However, the new field does not have the conceptual terminology of its own yet. Nor does it have research-based methodological tools for effective management of Robotic Process Automation (Sobczak, 2019). Thus, 
the administration of RPA must be based on the essential Business Process Management discipline (Kirchmer and Franz, 2019).

To sum up, the benefits created by RPA for an organisation have an impact on PM, as RPA is one of the technologies that is fundamentally revolutionising workplaces. Automation can lead to changes in the architecture of organisational processes in general, its redesign, and encourage innovation in processes. On the other hand, PM has an impact on RPA, as new business models and processes are developed considering further implementation of RPA. The analysis of the selected scientific sources provided in this article reveals some of the aspects described below related to the interrelations between PM and RPA.

\section{The technical and human aspects}

The technical and human aspects are essential in the context of the interrelation between PM and RPA. L. B. L. Amui et al. (2017) treat the technical aspect as an area that includes technologies, structure, technical knowledge, and processes. The human aspect involves training, decisions, cultures, and teams. Most of the selected scientific sources analyse the technical aspect at the organisation level, focusing mainly on the processes, enhancing their efficiency and effectiveness, and quality improvement. Only a few selected scientific sources cover the human aspect and the technical and human aspects. Several conceptual articles do not single out a specific aspect (Figure 2).

The research results based on the technical aspect reveal that the introduction of RPA is associated with cost reduction, increased quality for the desired outcome, faster processing, better level of compliance, and data accuracy. Management values and norms, other managerial insights that are essential factors encouraging organisations to reflect on robotics are emphasised. The introduction of RPA is based on both quantitative and qualitative objectives. It is emphasised that while the administration of RPA will eliminate many low-value jobs, many other jobs will be created. It has been observed that, in general, manual work poses many challenges for the organisation such as

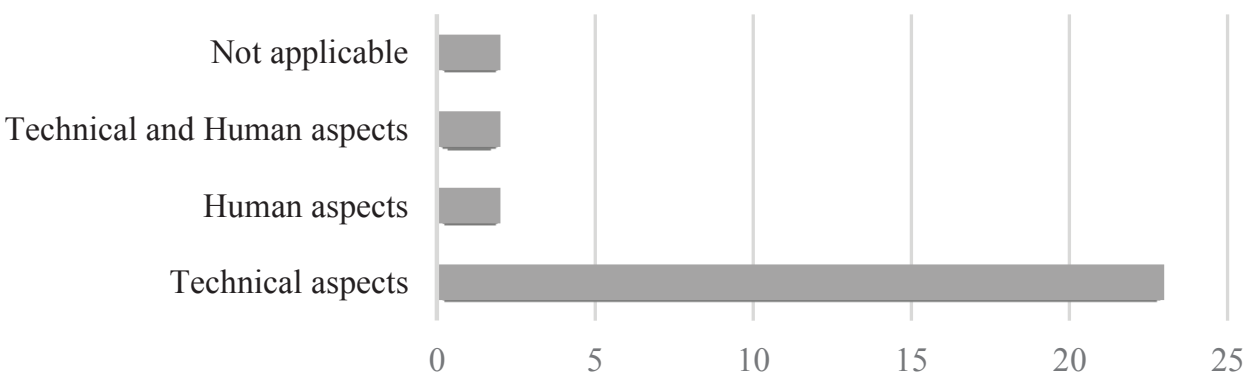

Fig. 2. Distribution of selected scientific papers for the category Technical and human aspects 
low motivation, low salaries (ZahariaRăduescu et al., 2017; Anagnoste, 2017; Anagnoste, 2018a; Anagnoste, 2018b; Hallikainen et al., 2018; Hofmann et al., 2020; Das, 2019; Kirchmer and Franz, 2019; Figueiredo and Pinto, 2020; Radke et al. 2020). This suggests that the innovative nature of the RPA outcomes provides value to consumers, which can usually be gained very quickly, increase process efficiency, and strengthen the relationship of management with Business Process Management as a holistic management approach. Failure to optimise the existing processes while introducing RPA can lead to inefficient administration, which does not produce the anticipated outcomes. Thus, organisations are committed to standardising and optimising operations. They adapt management structures to involve digital employees and redefine internal controls. Besides identifying cost savings, organisations experience improved process documentation, lower error rates, more accurate measurement of process performance, and better report quality (Šimek and Šperka, 2019a; Hofmann et al., 2020; Kokina and Blanchette, 2019).

P. Hofman et al. (2020) distinguish two groups of Key Performance Indicators (KPIs) that define the impact of RPA on business. The first group of KPIs includes internal factors such as employees' productivity enhancement, job satisfaction, process acceleration, or cost savings. The second group of KPIs includes external factors such as customers' satisfaction, cooperation with partners and suppliers, or stock market value. It is not only the reasons why organisations introduce RPA and what value it creates that are highlighted but also how this affects employees. It is noted that the successful administration of RPA increases employees' job satisfaction and their career prospects (Cooper et al., 2019).

However, the effects of RPA on employment are more complex than a simple replacement and substitution of workers (Figueiredo and Pinto, 2020). The main obstacle to successful automation of processes using RPA is the social acceptance and impact on the labour market, where job losses may be feared. Another critical factor is technical knowledge, as the acquisition of specific knowledge is relevant for implementing RPA (ZahariaRăduescu et al., 2017). Organisations emphasise the need for process owners who should be more tech-savvy and have better coding skills to decrease the reliance on IT for RPA support (Kokina and Blanchette, 2019). Thus, from a technical point of view, the issue of technical knowledge is also relevant.

Some scientific sources cover both the technical and human aspects. They analyse not only the processes, structures, technical knowledge but also the individual level, including learning, the teams formed, and the cultural aspect. It is stated that RPA technology has a significant impact on the individual and the organisation, which results in the change and reduction of work and creates unnecessary competition between humans and robots (Cooper et al., 2019; Fernandez and Aman, 2018). The study conducted by A. L. Cooper et al. (2019) revealed that the change in tasks given for accountants would require a different set of skills in the future. However, according to D. Fernandez and A. Aman (2018), the analytical facet could not be entirely replaced by robots and can only be done by humans. 
Two scientific papers that deal exclusively with the human aspect stand out. According to Y. M. Yunus et al. (2019), RPA not only contributes to the growth of marketplaces but also changes the individuals' experiences in using new technology. Emphasis is placed on business leaders' support, which is necessary to motivate and encourage IT users to innovate with the latest technology. R. Syed et al. (2020) explored how to trust a bot from the RPA users' perspective. While introducing RPA, organisations need to build mutual understanding between the operation teams and RPA designers, identify and cooperate with relevant stakeholders, build human users' confidence, and implement an effective change management plan.

\section{The national context}

One crucial aspect in the context of PM and RPA is the so-called national context. Information and communication technologies contribute substantially to economic growth not only in developed but also in developing and emerging countries (Niebel, 2018). Some of the research conducted on RPA and PM has also been linked to country-specific features. The analysis findings revealed that most of these topics are analysed in developed countries such as the United States, Romania, Switzerland, Finland, United Kingdom, Australia, etc., rather than developing countries such as Malaysia, Vietnam, and others (Figure 3).

Studies in emerging countries have not been found. However, it is essential to note that a significant number of articles (having filtered out the conceptual ones) did not mention a specific country, just indicating the international organisations involved in the study. Therefore, it cannot be argued that research has not been conducted in emerging countries as well.

Some scientific sources indicate that the study was conducted in the context of one country (Anagnoste, 2017; Fernandez and Aman, 2018; Yunus et al., 2019; Šimek and Šperka, 2019b; Sobczak, 2019; Figueiredo and Pinto, 2020; Korhonen et al., 2020), while other studies cover several countries (Anagnoste, 2018a; Kokina and Blanchette, 2019; Radke et al., 2020; Syed et al., 2020).

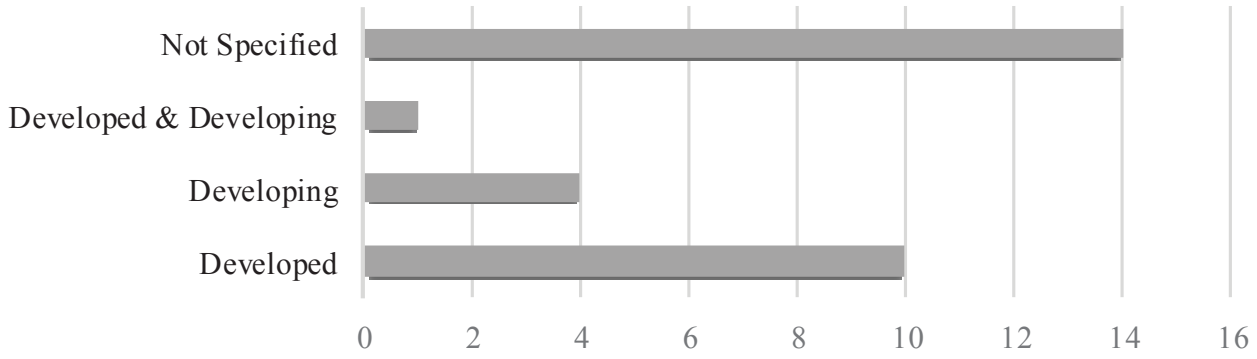

Fig. 3. Distribution of selected scientific papers for the category National context 
Since most of the research is conducted by developed countries, it can be argued that these countries are making rapid progress in robotising and managing processes, addressing the challenges of RPA and PM. However, it is evident that the challenges may differ in other countries because of the differences in culture and geography (Fernandez and Aman, 2018). Due to the ageing society, this topic is also relevant in developing countries (Anagnoste, 2018a).

\section{The economic sector}

Manufacturing and services, which play a crucial role in sustainable business development, also differ (Gunasekaran and Gallear, 2012). This study analyses which eco-nomic sector (services or manufacturing) was covered in the research in the selected scientific sources and what peculiarities of the process robotisation are revealed in different sectors. The review showed that scientific sources focus more on the service or cross-functional sectors, where both the service and manufacturing sectors are studied simultaneously. Seven of the references were not sector specific. These included conceptual sources and the sources in which a systematic review of the literature was conducted. Of these, several articles analyse a specific process without assigning it to a particular economic sector (Figure 4).

It should be noted that it is accounting, human resources, supply chain, document management, finance, administration, control processes in large pharmaceutical, oil \& gas organisations that are usually investigated (Anagnoste, 2017; Anagnoste, 2018a; Anagnoste, 2018b; Cooper et al., 2019; Fernandez and Aman, 2018; Hartley and Sawaya, 2019; Yunus et al., 2019; Kokina and Blanchette, 2019; Radke et al., 2020), as well as consulting, technology, telecommunication companies (Lacity et al., 2015; Šimek and Šperka, 2019a; Yunus et al., 2019), postal services and logistics providers (Hallikainen et al., 2018), machinery manufacturing organisations (Korhonen et al., 2020), and other large service and manufacturing organisations. Importantly, in some studies that analyse both service and manufacturing sectors, the authors do not even single out the research results applicable to one

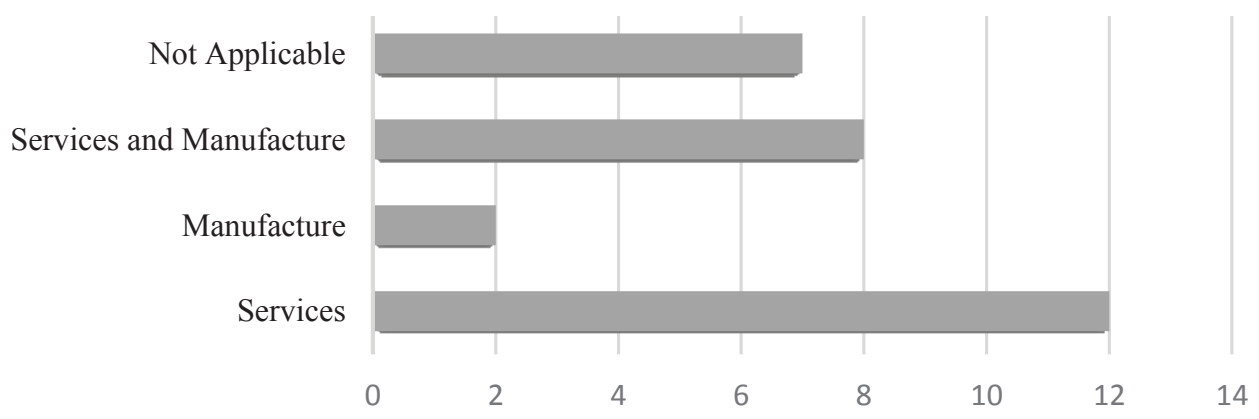

Fig. 4. Distribution of selected scientific papers for the category Economic sector 


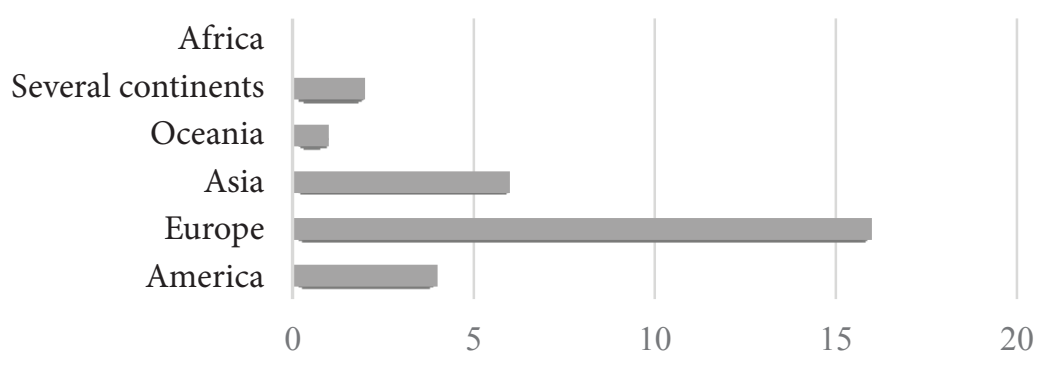

Fig. 5. Distribution of selected scientific papers for the category Geographical origin

Source: Clarivate Analytics/Web of Science (2021) and Scopus (2021). The authors' personal calculation.

of the sectors; the findings are attributed to both sectors (Anagnoste, 2017; Anagnoste, 2018a; Anagnoste, 2018b; Hartley and Sawaya, 2019; Kokina and Blanchette, 2019).

To sum up researchers' insights, it can be stated that from the managerial point of view, there are no significant differences between the sectors in the process of robotisation. The RPA tool typically automates processes in the areas of finance, accounting, supply chain, administration, and human resources that are common to the organisations of both the service and manufacturing sectors. When formulating recommendations, researchers do not single out the differences specific to a particular sector. U. Raissa et al. (2019) maintain that RPA has no industry specificity for its application. It is only the ability of companies to respond quickly to technological innovations that is considered to be relevant.

\section{The geographical origin}

Alongside the research conducted in developing and developed countries, another critical aspect is the geographical location of the sources reviewed considering authors' institutional affiliation (Amui et al., 2017). The vast majority of the scientific papers originated from the European continent (Anagnoste, 2017; Anagnoste, 2018a; Anagnoste, 2018b; Šimek and Šperka, 2019a; Ivančić, et al. 2019; Hofmann et al., 2020; Figueiredo and Pinto, 2020). A smaller number of scientific sources are from Asia and America (Fernandez and Aman, 2018; Hartley and Sawaya, 2019; Radke et al., 2020). Some articles have come from several continents, such as Europe and America, Oceania, and Europe (Hallikainen et al., 2018; Kirchmer and Franz, 2019) (Figure 5).

Considering the participation of scholars in joint research on a country and continent basis, it is noticeable that there is a lot of room for collaborative research in the future, as only two scientific papers have been developed in intercontinental cooperation (Hallikainen et al., 2018; Kirchmer and Franz, 2019). A few studies have been conducted between certain countries on the same continent (Korhonen et al., 2020; Radke et al., 2020). The importance of the geographical principle 


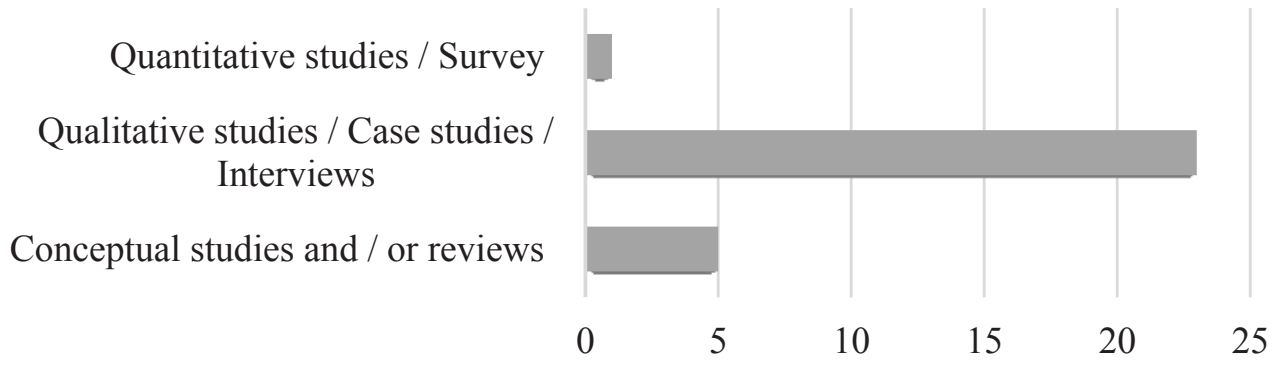

Fig. 6. Distribution of selected scientific papers for the category Research methods

Source: Clarivate Analytics/Web of Science (2021) and Scopus (2021). The authors' personal calculation.

is also emphasised by A. L. Cooper et al. (2019). In their study, the scholars outline the importance of future research in RPA and PM in regional and local accounting organisations.

\section{The research methods}

The analysis of the selected scientific sources reveals that the dominant investigations into the interrelationships between PM and RPA are qualitative studies using case analysis and interview methods. Only one study found is quantitative and is conducted using the survey method (Das, 2019). Five scientific sources are conceptual in nature or based on reviews, for instance, using the systematic literature review method (Figure 6). No studies combining qualitative and quantitative methods using surveys, interviews, case studies have been found.

A vital feature of the case study research design is replicating, or several instances included in a project (Yunus et al., 2019). Some authors researched more than one organisation in their studies, i.e., analysed multiple cases (Yunus et al., 2019; Kokina and Blanchette, 2019) or conducted two-case investigations (Anagnoste, 2018a, Šimek and Šperka, 2019b; Radke et al., 2020).

To sum up, the study of the strategies used by researchers disclosed that the interrelationship between PM and RPA is a novel topic that needs to be developed in future research. The qualitative research results (obtained using the survey method) should be assessed quantitatively and combining quantitative and qualitative methods, which will increase the statistical validity of the findings and elaborate the theoretical insights in this context. This is also emphasised by J. Kokina and Sh. Blanchette (2019), who note that future research could employ a survey or experimental methodology to enhance the generalizability of research findings. Meanwhile, having conducted a quantitative study, A. Das et al. (2019) intend to expand their empirical study with focus group discussions and case-oriented deep dives on RPA implementations.

\section{Results and discussion}

Effective implementation of RPA is a multifaceted issue, covering both managerial 
and technological aspects. In other words, it is an area of interdisciplinary research at the centre of robonomics (Sobczak, 2019). In this context, this IT tool is defined as value-driven RPA, a part of a discipline of process-led digital transformation management, leveraging the capabilities of Business Process Management to realise the total value of digital initiatives, fast and at minimal risk (Kirchmer and Franz, 2019). The interrelationship between PM and RPA is inseparable. This is revealed while investigating both technical and human aspects in the organisations implementing RPA while assessing processes, structure, technical knowledge, culture, etc. All these components aim to create value in the organisation, increasing the efficiency and effectiveness of operations, the quality of services provided, and the product produced.

Research on this topic is most active in developed countries in Europe in the service sector. However, such research is already emerging on other continents. The dominant investigations into the interrelationships between PM and RPA are qualitative studies using case analysis and interview methods. It should be noted that based on the findings of this research, the topics of RPA and PM are equally relevant in the service and manufacturing sectors in large, medium, and small organisations. To gain more meaningful insights into the development of both practice and theory, future research should focus on more diverse aspects. It is also purposeful to use both quantitative and qualitative research methods in combination, as such investigations are now based exclusively on qualitative research applying case study and interview methods.
The systematic literature analysis, based on quantitative and qualitative aspects, revealed relevant insights for future research on this topic. Based on the findings, the detailed research gaps have been outlined.

Based on researchers' insights, the precisely pinpointed need for future research in the context of the interrelationships between PM and RPA is related to identifying challenges and solutions in the implementation of RPA to help organisations more fully realise the gains from RPA. The research on specific topics such as the effects of RPA for regional and local accounting firms, how this technology will evolve in the future, whether the market itself trusts robots, and how customers respond to such process changes is also purposeful. It is desirable in the future to identify employees' characteristics that might help them better adapt to technological change (Cooper et al., 2019). New opportunities for the research related to the tension and contradictions arising from the progressive institutionalisation of robotisation in service organisations are highlighted. It is also appropriate to determine the practical impact of RPA on a broader institutional and business ecosystem (Figueiredo and Pinto, 2020), looking further into the role of organisation and institutions in IT innovation (Yunus et al., 2019), exploring the relationship between RPA-suitable processes criteria and RPA success (Santos et al., 2020). It is emphasised that organisational and IT strategy, governance structures, and management systems must address both the direct effects of software robot automating processes and their indirect impacts on organisations. In other words, the organisational impact includes the 
implications of RPA deployment for human labour and the process landscape. It is also proposed to define suitable performance measures when the long-term impact of RPA on the organisation as a whole, its employees, their job satisfaction and retention is being assessed (Hofmann et al., 2020; Kokina and Blanchette, 2019).

To sum up, the interrelationship between PM and RPA from a managerial perspective is highly relevant in this review of the selected scientific literature; and the need for targeted research in Robotic Process Management stands out.

\section{Conclusions}

The article analyses the scientific literature and identifies the gaps and insights in the research related to interrelationships between PM and RPA from the managerial perspective. Scientific sources have been classified to pinpoint the future research framework. The article contributes to deepening the understanding of the interrelationships between PM and RPA by systematically reviewing scientific sources published in Clarivate Analytics/ Web of Science and Scopus databases in 1990-2021. Thus, answering the scientific question raised in this article, what the interrelationship between PM and RPA from the managerial perspective is, it should be noted that the link between PM and RPA is inseparable. The benefits created by RPA for an organisation have an impact on PM, as RPA is one of the technologies that is fundamentally revolutionising workplaces. Automation can lead to changes in the architecture of organisational processes in general, its redesign, and encourage innovation in processes. On the other hand, PM has an impact on RPA, as new business models and processes are developed considering further implementation of RPA. The importance of this link is actualised in the service and manufacturing industries from both technical and, especially, human point of view, and the research results are mostly based on the qualitative investigations conducted in the developed countries.

Future research should focus on both practice and the development of theory in the context of investigations into Robotic Process Management. To effectively and efficiently manage robotic processes in practice, the application of the results of further research on this topic in practice is highly relevant. As the lack of scientific knowledge in this area is highlighted, it is important to clarify the definitions of PM and RPA interrelationships and the outcomes of those interactions, based on scientific research.

The article does have restrictions. Firstly, the literature review was limited to pre-defined keywords and two specific databases. Therefore, in the future, it is purposeful to expand the scope of the search by increasing the number of keywords (for instance, "business process improvement", "business process management", "reengineering", "redesign", etc.) and including other popular and accessible databases. Besides, not all scientific sources were attainable, as only those published in English have been analysed. 


\section{References}

1. Akdil, K. Y., Ustundag, A., Cevikcan, E. (2018). Maturity and Readiness Model for Industry 4.0 Strategy / In Industry 4.0: Managing the Digital Transformation, ed. A. Ustundag and E. Cevikcan - Springer, Cham, pp. 61-94. doi: 10.1007/978-3-319-57870-5_1

2. Amui, L. B. L., Jabbour, Ch. J. Ch., de Sousa Jabbour, A. B. L., Kannan, D. (2017). Sustainability as a Dynamic Organizational Capability: A Systematic Review and a Future Agenda toward a Sustainable Transition // Journal of Cleaner Production. Vol. 142, No. 1, pp. 308-322. doi: 10.1016/j.jclepro.2016.07.103

3. Anagnoste, S. (2017). Robotic Automation Process - The Next Major Revolution in Terms of Back Office Operations Improvement // Proceedings of the $11^{\text {th }}$ International Conference on Business Excellence. 11(1), pp. 676-686. doi: 10.1515/picbe-2017-0072

4. Anagnoste, S. (2018a). Robotic Process Automation in Pharma: three case studies // Conference: BASIQ 2018 New Trends in Sustainable Business and Consumption. At: 31 May-3 June 2018, Heidelberg, Germany. Internet access: https://www.researchgate. net/publication/338685569_ROBOTIC_ PROCESS_AUTOMATION_IN_PHARMA_ THREE_CASE_STUDIES. [accessed January 6, 2021].

5. Anagnoste, S. (2018b). Robotic Automation Process - The operating system for the digital enterprise // Proceedings of the International Conference on Business Excellence. Vol. 12(1), pp. 54-69. doi: 10.2478/picbe-2018-0007

6. Bloem, J., Doorn, Van M., Duivestein, S., Excoffier, D., Maas, R., Ommeren, van E. (2014). The Fourth Industrial Revolution Things to Tighten the Link Between IT and OT. Sogeti: VINT2014. Internet access: https://www. sogeti.com/globalassets/global/special/ogetithings3en.pdf. [accessed January 6, 2021].

7. Brocke, vom J., Maaß, W., Buxmann, P., Maedche, A., Leimeister, J. M., Pecht, G. (2018). Future Work and Enterprise System // Business \& Information Systems Engineering. Vol. 60, No. 4, pp. 357-366. doi: 10.1007/s12599-018-0544-2

8. Buzavaite, M., Korsakiene, R. (2019). Human Capital and the Internationalisation of SMEs: A Systemic Literature Review // Entrepreneurial Business and Economics Review. Vol. 7, No. 3, pp. 125-142. doi: 10.15678/EBER.2019.070307
9. Cooper, A. L., Holderness, K., Sorensen, L. T., Wood. A. D. (2019). Robotic Process Automation in Public Accounting // Accounting Horizons. Vol. 33, No. 4, pp. 15-35. doi: 10.2139/ ssrn.3193222

10. Das, A. (2019). Robotic process automation: assessment of the technology for transformation of business processes // International Journal of Business Process Integration and Management. Vol. 9, No. 3, pp. 220-230. doi: 10.1109/ CBI.2019.10089

11. Dumas, M., Rosa, La M., Mendling, J., Reijers, A. H. (2018). Fundamentals of Business Process Management. $2^{\text {nd }}$ ed. - Springer.

12. Fernandez, D., Aman, A. (2018). Impacts of Robotic Process Automation on Global Accounting Services // Asian Journal of Accounting \& Governance. Vol. 9, pp. 123-131. doi: 10.17576/AJAG-2018-09-11

13. Figueiredo, A. S., Pinto, L. H. (2019). Robotizing Shared Service Centres: Key Challenges and Outcomes // Journal of Service Theory and Practice. Vol. 31, No. 1, pp. 157-178. doi: 10.1108/JSTP-06-2020-0126

14. Fischer, M., Imgrund, F., Janiesch, Ch., Winkelmann, A. (2019). Directions for Future Research on the Integration of SOA, BPM, and BRM // Business Process Management Journal. Vol. 25, No. 7, pp. 1491-1519. doi: 10.1108/ BPMJ-05-2018-0130

15. Gunasekaran, A., Gallear, D. (2012). Special Issue on Sustainable Development of Manufacturing and Services // International Journal of Production Economics. Vol. 140, No. 1, pp. 1-6. doi: 10.1016/j.ijpe.2012.07.005

16. Hallikainen, P., Bekkhus, R., Pan L. Sh. (2019). How OpusCapita Used Internal RPA Capabilities to Offer Services to Clients // MIS Quarterly Executive. Vol. 17, No. 1, pp. 41-52. Internet access: https://www.researchgate.net/ publication/323723506_How_OpusCapita_ used_internal_RPA_capabilities_to_offer_ services_to_clients. [accessed January 6, 2021].

17. Hartley, L. J., Sawaya, J. W. (2019). Tortoise, not the Hare. Digital Transformation of Supply Chain Business Processes // Business Horizon, Vol. 62, No. 6, pp. 707-715. doi: 10.1016/j. bushor.2019.07.006

18. Hofmann, P., Samp, C., Urbach, N. (2020). Robotic process automation // Electronic 
Markets. Vol. 30, pp. 99-106. doi: 10.1007/ s12525-019-00365-8

19. Huang, F., Vasarhelyi, M. A. (2019). Applying robotic process automation (RPA) in auditing: A framework // International Journal of Accounting Information Systems. Vol. 35. doi: 10.1016/j.accinf.2019.100433

20. Ivančić, L., Vugec, S. D., Vukšić, B. V. (2019). Robotic Process Automation: Systematic Literature Review / In book: Business Process Management: Blockchain and Central and Eastern Europe Forum. Vol. 361, pp. 280-295. doi: 10.1007/978-3-030-30429-4_19

21. Jabbour, Ch. J. Ch. (2013). Environmental Training in Organisations: From a Literature Review to a Framework for Future Research // Resources, Conservation and Recycling. Vol. 74, pp. 144-155. doi: 10.1016/j. resconrec.2012.12.017

22. Kirchmer, M., Franz, P. (2019). Value-Driven Robotic Process Automation (RPA). A ProcessLed Approach to Fast Results at Minimal Risk // In Business Modelling and Software Design, ed. B. Shishkov. Vol. 356, pp. 31-46. BMSD 2019. Lecture Notes in Business Information Processing. Springer, Cham. doi: 10.1007/978-3-030-24854-3_3

23. Kokina, J., Blanchette, Sh. (2019). Early Evidence of digital labor in accounting: Innovation with Robotic Process Automation // International Journal of Accounting Information Systems. Vol. 35. doi: 10.1016/j.accinf.2019.100431

24. Korhonen, T., Selos, E., Laine, T., Suomala, P. (2020). Exploring the Programmability of Management Accounting Work for Increasing Automation: An Interventionist Case Study // Accounting, Auditing \& Accountability Journal. Vol. 34, No. 2, pp. 253-280. doi: 10.1108/ AAAJ-12-2016-2809

25. Kumar, N. K., Balaramachandran, P. R. (2018). Robotic Process Automation - a Study of the Impact on Customer Experience in Retail Banking Industry // Journal of Internet Banking and Commerce. Vol. 23 No. 3, pp. 1-27. Internet access: https://www.icommercecentral.com/ open-access/robotic-process-automation-astudy-of-the-impact-on-customer-experiencein-retail-banking-industry.php?aid $=87176$. [accessed January 10, 2021].

26. Lacity, M., Willcocks, L., Craig, A. (2015). Robotic Process Automation: Mature Capabilities in the Energy Sector / The Outsourcing Unit Working Research Paper
Series 15/06. The London School of Economics and Political Science, London, UK. Internet access: http://eprints.lse.ac.uk/64520/. [accessed January 11, 2021].

27. Leshob, A., Bourgouin, A., Renard, L. (2018). Towards a Process Analysis Approach to Adopt Robotic Process Automation // IEEE $15^{\text {th }}$ International Conference on e-Business Engineering (ICEBE). doi: 10.1109/ ICEBE.2018.00018.

28. Mamoghli, S., Cassivi, L., Trudel, S. (2018). Supporting Business Processes through Human and IT Factors: A Maturity Model // Business Process Management Journal. Vol. 24, No. 4, pp. 985-1006. doi: 10.1108/BPMJ-11-2016-0232

29. Martinez, F. (2019). Process Excellence the Key for Digitalisation // Business Process Management Journal. Vol. 25, No. 7, pp. 1716 1733. doi: 10.1108/BPMJ-08-2018-0237

30. Niebel, Th. (2018). ICT and Economic Growth Comparing Developing, Emerging and Developed Countries // World Development, Vol. 14, pp. 197-211. doi: 10.1016/j. worlddev.2017.11.024

31. Onar, S. S., Ustundag, A. (2018). Smart and Connected Product Business Models // In Industry 4.0: Managing the Digital Transformation, ed. A. Ustundag and E. Cevikcan, 25-41. - Springer, Cham. doi: 10.1007/978-3-319-57870-5_1

32. Pereira, V. R., Maximiano, A. C. A., Bido, de Souza D. (2019). Resistance to Change in BPM Implementation // Business Process Management Journal. Vol. 25, No. 7, pp. 1564 1586. doi: 10.1108/BPMJ-07-2018-0184

33. Radke, A. M., Dang, M. T., Tan, A. (2020). Using Robotic Process Automation (RPA) to Enhance Item Master Data Maintenance Process // Scientific Journal of Logistics. Vol. 16, No. 1, pp. 129-140. Doi: 10.17270/J. LOG.2020.380

34. Raissa, U., Aiman, M., Zhyldyz, K., Aizhan, K., Ryskhan S. (2019). Applying of RPA in Administrative Processes of Public Administration // IEEE 21 $1^{\text {st }}$ Conference on Business Informatics (CBI). Pp 9-12. doi: 10.1109/CBI.2019.10089

35. Ranerup, A., Henriksen, H. Z. (2019). Value Positions Viewed through Lens of Automated Decision Making: The Case of Social Services // Government Information Quarterly. Vol. 36, No. 4, pp. 1-13. doi: 10.1016/j.giq.2019.05.004 
36. Santos, F., Pereira, R., Vasconcelos, B. J. (2020). Toward Robotic Process Automation Implementation: An End-to-End Perspective // Business Process Management Journal. Vol. 26, No. 2, pp. 405-420. doi: 10.1108/ BPMJ-12-2018-0380

37. Siderska, J. (2020). Robotic Process Automation - a Driver of Digital Transformation? // Engineering Management in Production and Services. Vol. 12, No. 2, pp. 2131. doi: 10.2478/emj-2020-0009

38. Šimek, D., Šperka, R. (2019a). Is Robotic Process Automation (RPA) Disrupting the Market with Business Process Management (BPM) Solutions? // $2^{\text {nd }}$ International conference on Decision making for Small and Medium-Sized Enterprises DEMSME, pp. 244-251. ISBN 978-80-7510-339-0.

39. Šimek, D., Šperka, R. (2019b). How Robot/ human Orchestration Can Help in an HR Department: A Case Study from a Pilot Implementation // Organizacija. Vol. 52, No. 3, pp. 204-217. Doi: 10.2478/orga-2019-0013

40. Sobczak, A. (2019). Building a Robotic Capability Map of the Enterprise // Management Issues. Vol. 5, No. 85, pp. 132-154. doi: 10.7172/1644-9584.85.8

41. Syed, R., Suriadi, S., Adams, M., Bandara, W., Leamans, S. J. J., Chun, O., Hofstede, H. M. ter A., Weerd van der I., Wynn, Th. M., Reijers, A. H. (2020). Robotic Process Automation: Contemporary Themes and Challenges // Computers in Industry. Vol. 115. doi: 10.1016/j.compind.2019.103162

42. Szelagowski, M., Berniak-Woźny, J. (2020). The Adaptation of Business Process Management Maturity Models to the Context of the Knowledge Economy // Business Process Management Journal. Vol. 26, No. 1, pp. 212238. doi: 10.1108/BPMJ-11-2018-0328
43. Thomas, A. (2020). Convergence and Digital Fusion Lead to Competitive Differentiation // Business Process Management Journal. Vol. 26, No. 3, pp. 707-720. doi: 10.1108/ BPMJ-01-2019-0001

44. Wang, Q., Waltman, L. (2016). Large-scale Analysis of the Accuracy of the Journal Classification Systems of Web of SCIENCE and Scopus // Journal of Infometrics. Vol. 10, pp. 347-364. doi: 10.1016/j.joi.2016.02.003

45. Willcocks, L. (2020). Robo-Apocalypse Cancelled? Reframing the Automation and Future of Work Debate // Journal of Information Technology. Vol. 35, No. 4, pp. 286-302. doi: $10.1177 \% 2$ F0268396220925830

46. Xiao, Y., Watson, M. (2019). Guidance on Conducting a Systematic Literature Review // Journal of Planning Education and Research. Vol. 39, No. 1, pp. 93-112. doi: $10.1177 / 0739456 \mathrm{X} 17723971$

47. Yunus, Y. M., Aman, A., Keliwon K. B. (2019). The Role of Business Leaders in Information Technology Innovation in the New Era of Disruptive Technology of Web of Science and Scopus // Asian Journal of Accounting and Governance. Vol. 12, pp. 133-142. doi: 10.17576/AJAG-2019-12-11

48. Zaharia-Răduescu, A., Pricop, C. L., Shuleski, D., Ioan, A. Ch. (2017). RPA and the Future of Workforce // Proceedings of the $11^{\text {th }}$ International Management Conference. The Role of Management in the Economic Paradigm of the XXIst Century. Vol. 11, No. 1, pp. 384-392.

The paper submitted: April 15, 2021 Prepared for publication: July 30, 2021

\section{Inga STRAVINSKIENĖ, Dalius SERAFINAS}

\section{PROCESU VADYBA IR ROBOTINIS PROCESU AUTOMATIZAVIMAS: IZZVALGOS, GRINDŽIAMOS SISTEMINE LITERATŪROS APŽVALGA}

S a n t r a u k a

Ketvirtosios pramonès revoliucijos laikotarpiu skaitmeninè transformacija revoliucionizuoja tiek individualias organizacijas, tiek ištisas industrijas. Technologijos jau nebeatlieka tik pagalbinès funkcijos. Tam tikrais atvejais jos pakeičia rankinị darbą. Viena iš tokių pažangių technologijų - robotinis procesų automatizavimas. Vis daugiau demesio šiai technologijai ir jos kuriamai vertei skiriama tiek akademinès, tiek praktinès perspektyvos vadybiniu aspektu. 
Vis dèlto nepaisant itin sparčios technologijų kaitos, ne visuomet organizacijos pasiekia pažangą, kokios tikèjosi, pasitelkdamos naujausias technologijas veiklos procesų efektyvumui didinti. Šiame kontekste aktualizuojama organizacijos procesų vadyba. Akivaizdu, jog RPA negali būti atsietas nuo organizacijų vadybos, ypač nuo procesų vadybos. Vis dèlto sąsajos tarp procesų vadybos ir RPA mokslinèje literatūroje iki šiol mažai tyrinètos. Stokojama procesų vadybos ir RPA tematikų sintezès, jų tarpusavio sąsajų ižvalgų. Ši tema ypač aktuali ketvirtosios pramonès revoliucijos kontekste.

Šiame straipsnyje, taikant sisteminès literatūros apžvalgos metodą, siekiama užpildyti spragą procesų vadybos ir RPA sąsajų tematika vadybiniu aspektu, taip identifikuojant mažiau tyrinètas sritis ir suformuluojant rekomendacijas būsimiems tyrimams. Atliekant sisteminę literatūros apžvalgą, vykdyta kiekybinè ir kokybinè literatūros šaltinių analizè. Kiekybiškai tyrimas grindžiamas atitinkamos literatūros klasifikavimo požiūriu. Kokybiniu aspektu atlikta mokslinių šaltinių analizè.

Gauti rezultatai atskleidè, kad procesų vadybos ir RPA sąsaja, kaip tarpdisciplininių tyrimų sritis, naujausiuose moksliniuose tyrimuose itin aktualizuojama. Tą atskleidžia techninių ir žmogiškuju aspektų tyrinejjimas RPA diegiančiose organizacijose, vertinant veiklos procesus, struktūrą, technines žinias, kultūrą ir kt. Visos minètos dedamosios nukreiptos ị vertès kūrimą organizacijoje, didinant jos veiklos procesų efektyvumą, rezultatyvumą, teikiamų paslaugų, gaminamo produkto kokybę. Vis dèlto šiuos aspektus tikslinga tolesniuose tyrimuose labiau sieti su žmogiškuoju aspektu. RPA ir procesu vadybos tematika vienodai aktuali paslaugų ir gamybos sektoriuose ir didelèse, vidutinèse, mažose organizacijose. Būsimi tyrimai turètų būti sutelkti ị minètus skirtingus aspektus, siekiant reikšmingesnių įžvalgų robotizuotų procesų vadybos tyrimų praktikoje ir teorijos kontekste. 